\title{
Perception-Need Theory of Meaning: Definition and Demonstration
}

\author{
Etienne Mupemba Kabwe Kantanda \\ Department of English and African Culture, High Teacher Training College, Mbujimayi, Democratic Republic of Congo
}

\section{Email address:}

etienemupemba $a$ yahoo.fr, etiennemupemba@gmail.com

\section{To cite this article:}

Etienne Mupemba Kabwe Kantanda. Perception-Need Theory of Meaning: Definition and Demonstration. Communication and Linguistics Studies. Vol. 4, No. 2, 2018, pp. 37-44. doi: 10.11648/j.cls.20180402.13

Received: June 2, 2018; Accepted: June 19, 2018; Published: July 9, 2018

\begin{abstract}
There are many theories of meaning such as semantic theories (Rusellianism, fregeanism, Possible World Semantics, Davidsonianism, Internalist theories, etc and foundational theories of meaning (Gricean Program, interpretational theories, etc). Philosophers of language such as Russell, Frege, Grice, Davidson, and Chomskyan internalists have constructed theories of meaning by focusing on the following elements as meaning determiners: referent, property, thought, circumstances, truth-condition, intention, language faculty, interpretation, causes, use, representations, and idea. None of these philosophers of language has thought of "speaker's need" which is the core element on which the above elements are based in order to state what determines meaning. Therefore, the objective of this article is to demonstrate how the perception of the speaker's need by the listener or hearer determines meaning in a linguistic communication. This demonstration is based on the results of a research conducted in Bonzola Hospital (a hospital in Mbujimayi City in Democratic Republic of Congo. The data in this study were collected through observation and interview. The observation consisted in attending the interaction between doctors and patients so as to listen to their utterances and watch their gestures, facial expressions, actions and whatever can occur during their communication. As far as the analysis of data is concerned, the Conversation Analysis was used so as to analyze the utterances, facial expressions, actions, gestures, and other elements that can occur in communication between doctors and patients. The results show clearly that the conveyance and reception of meaning does not depend mainly on referent, property, thought, circumstances, truth-condition, intention, language faculty, interpretation, causes, use, representations, and idea but the conveyance and reception of meaning depend on the perception of the speaker's need by the listener or hearer. The interpretation of the results led to the conclusion that meaning is determined by the perception of the speaker's need by the listener or hearer.
\end{abstract}

Keywords: Meaning, Theory, Need, and Perception

\section{Introduction}

The researchers interested in meaning such as Grice, Russell, Frege, Davidson, and the others constructed theories in order to point out what determines meaning of an expression. Their theories pointed out different elements which, according to them, determine meaning of an expression. These elements are referent, property, thought, circumstances, truth-condition, intention, language faculty, interpretation, causes, use, representations, and idea. But when a research was conducted in order to know how meaning is conveyed and received in doctor-patient communication in Bonzola Hospital, the results revealed that meaning of an expression is determined by the perception of the speaker's need by the listener or hearer of the speaker's expression. None of the theories of meaning has focused on the perception of need as an important element which determines meaning and which is the basis of elements pointed out in the existing theories.

Therefore, this article aims at demonstrating how meaning of an expression is determined by the perception of the speaker's need. To reach this aim, this article reviews the existing theories of meaning, and it demonstrates (by referring to some of interactions between doctors and patients) how meaning is determined by the perception of the speaker's need by the listener or hearer of the speaker. 


\section{Background}

\subsection{Semantic Theories}

Stanford Encyclopedia of Philosophy [39] states that "the first sort of theory - a semantic theory - is a theory which assigns semantic contents to expressions of a language". It is obvious that words and expressions can be assigned meaning by the users of languages. A word or an expression can be assigned various meanings according to the speaker's need. Let us consider the following conversation between a doctor and a patient:

Doctor: Have you respected the rest I recommended to you?

Patient: Yes. I have not worked for six months.

Doctor: Do you sleep with your wife?

Patient: We share the same bed.

Doctor: Do you have sex with her?

Patient: yes.

Doctor: You should not have sex with her. I told you to have a rest for six months.

In this conversation, for the speaker's meaning (the doctor's meaning) of the word rest meant not to do any work and not to have sex intercourse. But for the patient, the same term meant only to stop working. This is to say that the doctor has assigned the word rest meaning which was not grasped by the patient.

Semantic theories are subdivided into propositional and non-propositional semantic theories. Propositional semantic theories are concerned with Platonist theories such as Russellianism, Fregeanism and Possible worlds semantics. Non-propositional semantics deals with Davidsonian theories, Internalist theories and Skepticism about meaning.

\subsubsection{Propositional Semantic Theories}

Speaks [38] writes that "on their face, claims that a certain linguistic expression means such-and-such are claims that a certain relation - the meaning relation - holds between expressions and a certain kind of entity, the meaning of that expression".

According to Platonist theories there is a relationship between an expression or utterance and the entity of that expression or utterance.

Speaks [38] suggests three leading answers to the question "what kinds of things are meanings?" which are the following.

\section{i. Russellianism}

The first leading answer that Speaks suggests is Russellianism. He states that

on one view, the meanings of expressions are the same sorts of things that are the constituents of facts: objects and properties in the world. On some versions of this view, the meaning of a simple name is the object for which it stands, and the meaning of a simple predicate is a property. (Properties are usually thought of as being similar to universals, or Plato's forms).

According to this point of view, the meaning of a word is the object for which it is referred to. This view can be slightly true if the object is a concrete thing and it is well known in the same way by both the speaker and the hearer. But in the case that the object is an abstract thing, this view is totally wrong. For example, the word pain has no object that stands for it, except the idea of it.

\section{ii. Fregeanism}

Fregeanism is the second leading answer that Speaks suggests to the question what kind of things are meanings. Speaks [38] writes that

Fregeans offer a more fine-grained approach to meanings. On one version of the view (which is not exactly Frege's) the meaning of a name is not an object, but a way of thinking about an object, and the meaning of a predicate is not a property, but a way of thinking about a property. Frege called these 'ways of thinking about' about objects and properties senses.

According to this view, meanings are ways of thinking about an object and properties senses. It is obvious that a way of thinking depends on ones' knowledge, experience, environment, age, profession, studies, etc. Therefore, a way of thinking should not be thought as meaning, but meaning can be derived from a way of thinking. For example, a way of thinking of a doctor about a medicine is different from the one of a patient. This is to say that a way of thinking can be wrong or right. So to determine meaning of an utterance, a sentence, and other expressions one should focus on what the speaker needs to express.

\section{iii. Possible Worlds Semantics}

The last leading answer proposed by Speaks is possible worlds semantics which are sometimes called circumstances of evaluation. Speaks [38] comments that

Yet a third 'Platonist' approach to semantics identifies the meaning of a sentence with the set of circumstances which would make it true. On one version of this view, a circumstance is a way the world might have been - or, for short, a possible world. Then we can think of the meaning of a sentence as a set of possible worlds which would make it true.

The possible worlds are understood as situations that make the meaning of an expression real. The possible worlds should not be confused with context, character and content. 4.43201 Semantics and Pragmatics [1] writes that.

Kaplan introduces the notion of character and content. The former is the linguistic meaning of an expression, and the latter is the proposition (or propositional component) expressed by an expression in a context. Second, Kaplan makes an explicit distinction between the context of an utterance and the circumstances of evaluation of the proposition expressed by an utterance. Context can be formalized as a set composed of a speaker, a place, a time, and a possible world (...) Circumstances of evaluation play a role very similar to possible worlds in modal semantics.

\subsubsection{Non-propositional Semantic Theories}

Non-propositional semantic theories sustain that meaning 
of an expression cannot be paired with the expression. This assumption is supported by Wittengenstein quoted in 4.43201 Semantics and Pragmatics [1] who says: "you say: the point isn't the word, but its meaning, and you think of the meaning as a thing of the same kind as the word, though also different from the word. Here the word, there the meaning. The money, and the cow that you can buy with it".

Non-propositional semantic theories are explained through Davidsonian and internalist or Chomskyan theories.

\section{i. Davidsonian Theories}

Davidsonian theories focus on the conditions that make the meaning of an expression true. As Speaks [38] says that:

Donald Davidson, beginning "Truth and Meaning" (1967), rejected the Platonist idea that facts about meaning are facts about the relations between sentences and a special sort of entity. However, he wanted to preserve the link between the meanings of sentences and the conditions under which they are true.

\section{ii. Internalist Theories}

Internalist theories support the idea according to which the meaning of a sentence is a property which is characterized by its function in the language faculty. Speaks [38] argues that:

Chomskians, or internalists about meaning, give up both ideas: meanings are not entities distinct from linguistic expressions, and do not determine a set of truth-conditions. Rather (on some such views) the meaning of an expression is a property of that expression determined by its role in the language faculty of the user of the expression.

\subsection{Foundational Theories of Meaning}

Foundational theories try to find out an explanation about how expressions have meanings that they have. In 443201 Semantics and Pragmatics [1] it is written that "we no turn to our second sort of 'theory of meaning': foundational theories of meaning, which attempt to specify the facts in virtue of which expressions of natural languages come to have semantic properties that they have".

Foundational theories can be divided into two main categories which are mentalist theories and non-mentalist theories. The following lines discuss each of these categories in order to shed light on foundational theories of meaning.

\subsubsection{Mentalist Theories}

Mentalist theories focus more on mental representation than linguistic representation. Speaks [38] demonstrates that:

one intuitively plausible idea about the foundations of meaning is that the meanings of sentences are inherited from the thoughts of users of those sentences. On this view, mental representation is more fundamental than linguistic representation.

Mentalist theories are explained through Gricean program, the analysis of meaning in terms of belief, convention, and mental representation-based theories.

\section{i. The Gricean Program}

Paul Grice distinguishes sentence-meaning from speaker- meaning. The sentence-meaning relies on the compisitionality of a sentence whereas the Speaker-meaning is based on the communicative intention. Speaks [38] explains Gricean program in this way:

There are different ways of spelling out this idea. One, associated with Grice, claims that the meanings of sentences are determined by the contents of the communicative intentions of users of those sentences. Very roughly, the idea is that the meaning of a sentence is determined by what agents typically intend their audience to believe when they use the sentence.

\section{ii. Analysis of Meaning in Terms of Belief and Convention}

Other ideas which are associated to Gricean program are belief and convention. There is a relationship between utterances or sentences and belief of the person whom those utterances or sentences belong to. Speaks [38] illustrates the idea of belief in this way:

Another idea, associated with (among others) David Lewis, is that the meaning of a sentence is fixed by the beliefs with which the sentence is correlated. Perhaps, for example, the meaning of a sentence is the same as the content of the belief which most people would acquire upon hearing the sentence.

As belief (by itself) cannot be sufficient in analyzing the meaning, the analysis of meaning can be completed with convention. Convention relates to the truth that the community has about concerned utterances or sentences. In Stanford Encyclopedia [39] and [40] they explain the convention in this way:

There are different analyses of what it takes for a regularity to hold by convention; according to one important view, a sentence $\mathrm{S}$ expresses the proposition $\mathrm{p}$ if and only if the following three conditions are satisfied: (1) speakers typically utter $\mathrm{S}$ only if they believe $\mathrm{p}$ and typically come to believe p upon hearing $\mathrm{S}$. (2) members of the community believe that (1) is true, and (3) the fact that members of the community believe that (1) is true, and believe that other members of the community believe that (1) is true, gives them a good reason to go on acting so as to make (1) true.

\subsubsection{Non-mentalist Theories}

Non-mentalist theories examine the meanings of utterances or sentences in terms of the use of those utterances or sentences. Non-mentalist theories can be divided into interpretational theories, causal theories, use theories, and internalist theories.

\section{i. Interpretational Theories}

Interpretational theories focus on the person who assigns meaning to utterances or sentences according to her/his interpretation. Speaks [38] shows that "a different sort of approach, identified with Davidson, has it that the meanings of sentences are determined by what an ideal interpreter would assign as the meanings of sentences.

\section{ii. Causal Theories}

The analysis of meaning of an expression is based on the 
causes of that expression. Speaks [38] argues that "causal theories of meaning hold that the meaning of an expression is fixed neither by the thoughts of agents nor by what an ideal interpreter would say, but rather by the causes of utterances".

\section{iii. Use Theories}

Use theories of meaning state that the use of an expression determines the meaning of that expression. For Speaks [38] "the meaning of an expression is is determined by its use".

\section{iv. Internalist Theories}

Internalist theories are concerned with the relationship between representations and some parts of language faculty in the human brain. Speaks [38] explains that "on internalist theories, linguistic expressions are, first and foremost, representations in the brain. Internalists say that the meanings of these representations are fixed by their relations to other parts of the language faculty".

\section{v. Skepticism About Theories of Meaning}

Skepticism about meanings rejects all assumptions discussed above. They support the idea that facts about meaning do not exist. This is argued by Speaks [38] when he says that "opposed to all three of these approaches are theorists who say that, in some sense to be explicated, there are no facts about meaning". 4.43201 Semantics and Pragmatics [38] adds that "some philosophers of language
(Quine 1960; Kripke 1982; Soames 1999) deny that there are facts about the meanings of linguistic expressions. In that case, there can be no semantic/foundational theory of meaning, since no facts are there to be described or analyzed".

\section{Discussion}

In order to check how meaning is conveyed and received in doctor-patient communication, a research was conducted in Bonzola Hospital which is in Mbujimayi city (one of the cities in Democratic Republic of Congo). The expressions used in doctor-patient communication were analyzed in order to see how both doctors and patients grasp meaning of expressions in their interactions.

These expressions show that patients do not only focus on the linguistic meaning of words to grasp meaning of utterances; they also refer to what doctors need in asking questions. Doctors need to know patients' complaints so as to diagnose. Once patients get the actual need of doctors, they provide answers which seem not to pair with questions, but which are right answers. The following is some of interactions between doctors and patients. These interactions were mainly either in Ciluba (language spoken in Mbujimayi city) or in French. The utterances were translated into English so as to help the English readers understand.

\begin{tabular}{|c|c|}
\hline Doctor & $\begin{array}{l}\text { : Udiusamatshinyi? } \\
\text { What does she suffer from? }\end{array}$ \\
\hline Patient & $\begin{array}{l}\text { : Fièvre } \\
\text { Fever }\end{array}$ \\
\hline Doctor & $\begin{array}{l}\text { : Kukadimatukuanga? } \\
\text { How many days ago? }\end{array}$ \\
\hline Patient & $\begin{array}{l}\text { : Kukadimatukuanayi. } \\
\text { Four days ago. }\end{array}$ \\
\hline Doctor & $\begin{array}{l}\text { : Mundamusama? } \\
\text { Pain in the belly? }\end{array}$ \\
\hline Patient & $\begin{array}{l}\text { : Udi ni douleur yabunyi munda. } \\
\text { She has terrible pain in the belly. }\end{array}$ \\
\hline
\end{tabular}

The patient got the right meaning although the doctor's first question should not be asked to the patient since the patient is supposed not to know the disease that $\mathrm{s}$ /he is suffering from. The patient has perceived the doctor's need (which is to know the patient's complaint), and she responded to satisfy that need although the doctor's question was not appropriate. By asking the question "what does she suffer from?" the doctor's need was to know the patient complaint, but not the disease.

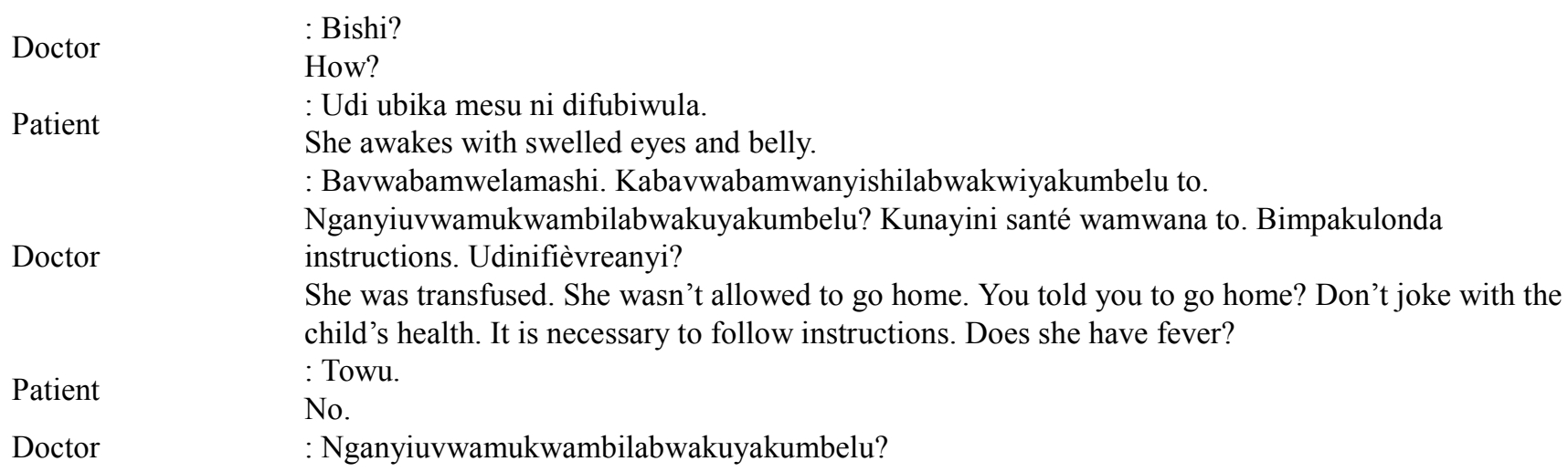


Who allowed you to go home?

\begin{tabular}{|c|c|}
\hline Patient & $\begin{array}{l}\text { : Mbayanyitshina. } \\
\text { My brother-in-low. }\end{array}$ \\
\hline Doctor & $\begin{array}{l}\text { : Ndi ne tshiakumona bayeba tshina ni ku mutandisha. Anu mesu anyi ? } \\
\text { I must see your brother-in-lo and scold him. Only eyes? }\end{array}$ \\
\hline Patient & $\begin{array}{l}\text { : Eyowa. } \\
\text { Yes. }\end{array}$ \\
\hline Doctor & $\begin{array}{l}\text { : Munda? } \\
\text { The belly? }\end{array}$ \\
\hline Patient & $\begin{array}{l}\text { : Ndimumonadiulaadi. } \\
\text { I see the swelling. }\end{array}$ \\
\hline Doctor & $\begin{array}{l}\text { : Tshiditshikwenzabowatshinyi? } \\
\text { What frightens you? }\end{array}$ \\
\hline Patient & $\begin{array}{l}\text { : Diula. } \\
\text { The swelling }\end{array}$ \\
\hline Doctor & $\begin{array}{l}\text { : Jaunemubangadibakayi? } \\
\text { When did the yellow start? }\end{array}$ \\
\hline Patient & $\begin{array}{l}\text { : Mudinayi. } \\
\text { On Thursday. }\end{array}$ \\
\hline Doctor & $\begin{array}{l}\text { : Ndi kuwesha rendez-vous anyima a lumingu. } \\
\text { I give you a rendezvous after a week. }\end{array}$ \\
\hline Patient & $\begin{array}{l}\text { : Eyowa. } \\
\text { Yes }\end{array}$ \\
\hline Doctor & $\begin{array}{l}\text { : Ndi kupesha rendez-vous mu disatu le } 14 \text {. } \\
\text { I give you the rendezvous on Wednesday the } 14^{\text {th }} .\end{array}$ \\
\hline
\end{tabular}

The patient has answered the first doctor's question by perceiving the doctor's need (the one of knowing what was going wrong with the child). The question "how" could not have an answer such as "she awakes with swelled eyes and belly", but in this context the answer has satisfied the doctor's need.

\begin{tabular}{|c|c|}
\hline Doctor & $\begin{array}{l}\text { : Bishi? } \\
\text { How? }\end{array}$ \\
\hline Patient & $\begin{array}{l}\text { : Bana aba badi ne fièvre. } \\
\text { These kids have fever. }\end{array}$ \\
\hline Doctor & $\begin{array}{l}\text { : Tshinyi ? } \\
\text { What is wrong with you (addressing to one of the kids)? }\end{array}$ \\
\hline Patient & $\begin{array}{l}\text { : Mutu. } \\
\text { The head. }\end{array}$ \\
\hline Doctor & $\begin{array}{l}\text { : Tshinyikabidi ? } \\
\text { What else? }\end{array}$ \\
\hline Patient & $\begin{array}{l}\text { : Fièvre. } \\
\text { Fever }\end{array}$ \\
\hline Doctor & $\begin{array}{l}\text { : Menyi adi ne couleur kayi ? } \\
\text { What color is urine? }\end{array}$ \\
\hline Patient & $\begin{array}{l}\text { Jaune. } \\
\text { Yellow }\end{array}$ \\
\hline Doctor & $\begin{array}{l}\text { : Tshinyitshikwabu? } \\
\text { What else? }\end{array}$ \\
\hline Patient & $\begin{array}{l}\text { : Muminu. } \\
\text { Throat }\end{array}$ \\
\hline Doctor & $\begin{array}{l}\text { : Udiudiabimpaanyi? } \\
\text { Does she eat well? }\end{array}$ \\
\hline Patient & $\begin{array}{l}\text { : Malaba ki mudia bimpa towu. } \\
\text { Yesterday, she did not eat. }\end{array}$ \\
\hline Doctor & $\begin{array}{l}\text { : Fièvreudibishi? } \\
\text { How is fever? }\end{array}$ \\
\hline Patient & $\begin{array}{l}\text { :Anyima a tusunsa. } \\
\text { After some minutes }\end{array}$ \\
\hline
\end{tabular}




\begin{tabular}{|c|c|}
\hline Doctor & $\begin{array}{l}\text { : Wewaebatshinyi? } \\
\text { What is wrong with you? }\end{array}$ \\
\hline Patient & $\begin{array}{l}\text { : Munda. } \\
\text { The belly }\end{array}$ \\
\hline Doctor & $\begin{array}{l}\text { : Menyiadiasama? } \\
\text { Urine hurts? }\end{array}$ \\
\hline Patient & : Moving the head from right to left and vice versa \\
\hline Doctor & $\begin{array}{l}\text { : Lukosu? } \\
\text { Cough? }\end{array}$ \\
\hline Patient & $\begin{array}{l}\text { : Towu. } \\
\text { No. }\end{array}$ \\
\hline Doctor & $\begin{array}{l}\text { : Badi balala mu moustiquaire anyi ? } \\
\text { Do they sleep in a mosquito net? }\end{array}$ \\
\hline Patient & $\begin{array}{l}\text { : Eyowa, kadimatuku aha badibabenga. } \\
\text { Yes. But these days they refuse. }\end{array}$ \\
\hline
\end{tabular}

In this interaction, doctor's question "how is fever" and the patient's answer "after some minutes" seem not to pair. But the meaning conveyed seems to be grasped. Therefore in this doctor-patient interaction, the perception of the speaker's need determines meaning.
Doctor
: Oui!
Yes!
: Andi inama. Unvwa diyi dianyi. Tshiena ni sinusite towu. Andi inama, mwaba ewu udi unsama. Mongu udi unsama. Diba dindi ngangata mukaji, Tshiena ngunvwa bukola towu.
Patient When I bow. Listen to my voice. I don't have sinusitis. When I bow this place (showing the part between the front and the nose) hurts me. The spine hurts me. When I take a wife. You don't feel force.
Doctor
: Pas de sinusite.
No sinusitis?
Patient
: Snusite to. Niva mwiya ku contrôle. Ndi ngunva douleur mu mikolo.
No sinusitis. I went to the control. (After some minute) I feel pain in my legs.

In this consultation, the doctor has asked a question with the word "yes" only. Fortunately, the patient has perceived the doctor's need (the one of knowing what was wrong with the patient) and answered to it. But the patient's answer sounds a bit strange. He mentioned seven problems without any coherence or cohesion. In the seventh problem, the patient substitutes himself by the doctor.

\begin{tabular}{|c|c|}
\hline Doctor & $\begin{array}{l}\text { : Bishi? } \\
\text { How? }\end{array}$ \\
\hline Patient & $\begin{array}{l}\text { : Bimpa. } \\
\text { Fine }\end{array}$ \\
\hline Doctor & $\begin{array}{l}\text { : Udi ne bwalukayi? } \\
\text { What's your problem? }\end{array}$ \\
\hline Patient & $\begin{array}{l}\text { : Tshienandjunva to. } \\
\text { I don't feel myself. }\end{array}$ \\
\hline Doctor & $\begin{array}{l}\text { : Wakadimusela? } \\
\text { Are you married? }\end{array}$ \\
\hline Patient & $\begin{array}{l}\text { :Towu. } \\
\text { No. }\end{array}$ \\
\hline Doctor & $\begin{array}{l}\text { : Wamanyibishi? } \\
\text { How do you know it? }\end{array}$ \\
\hline Patient & $\begin{array}{l}\text { : Ndinguvwa. } \\
\text { I feel. }\end{array}$ \\
\hline Doctor & $\begin{array}{l}\text { : Kwajikianyi? } \\
\text { That's all? }\end{array}$ \\
\hline Patient & $\begin{array}{l}\text { : Eyowa. } \\
\text { Yes. }\end{array}$ \\
\hline Doctor & : Menyiadiasamaanyi? \\
\hline
\end{tabular}




$\begin{array}{ll} & \text { Urine hurts? } \\ & : \text { Kenaasama to. } \\ \text { Patient } & \text { It does not hurt? } \\ & : \text { Fièvre? } \\ \text { Doctor } & \text { Fever? } \\ & : \text { Towu. } \\ \text { Patient } & \text { No. } \\ & : \text { Sucre mumubidi? } \\ \text { Doctor } & \text { Sugar in the body? } \\ \text { Patient } & \text { Sucre mumubidi? Towu. Oh Eyowa. Batu banteta anvwa musama malaria. } \\ & \text { Sugar in the body? No. Oh yes. They tested when I suffered from malaria. } \\ \text { Doctor } & \text { Let Benzamateta aha. }\end{array}$

The expression "I don't feel myself" used by the patient means "my penis is not erectile". The patient has spoken implicitly. Fortunately, the doctor perceived the patient's need in order to grasp the meaning of that expression.

\section{Results}

These interactions reveal that meaning is determined by the perception of the speaker's need by the listener or hearer. This is one of reasons why a word, a sentence or an utterance, a gesture, an action can have an infinite number of meanings depending on the hearer's perception of the speaker's need. Meaning is said to be meaning of that word, sentence, utterance, gesture or action if it is what constitutes the speaker's need. The speaker's need constitutes the basis of referent, property, thought, circumstances, truth-conditions, intention, language faculty, interpretation, causes, use, representations, and ideas which are elements mentioned in semantic and foundational theories of meaning. But none of these theories has mentioned the perception of speaker's need as an important element in determining meaning. Whenever the hearer does not perceive the speaker's need, s/he cannot grasp the meaning of what has been said, told, and spoken. This is what is called Perception-Need theory of meaning. That is, meaning of an expression in an interaction is determined by the perception of the speaker's need by the hearer through words, sentences, utterances, gestures, action, signs, etc.

\section{Conclusion}

To know what determines meaning of an expression, existing theories of meaning focused onreferent, property, thought, circumstances, truth-conditions, intention, language faculty, interpretation, causes, use, representations, and ideas as what determines meaning of an expression. The research conducted in Bonzola Hospital about how meaning is conveyed and received in doctor-patient communication revealed that meaning of an expression is determined by the perception of the speaker's need by the hearer through words, sentences, utterances, gestures, action, signs, etc.

\section{References}

[1] http://www.templeok.com/SP6 (2012) 4. 43201 Semantics and Pragmatics. Lectures 6 and 7: Theories of meaning.

[2] ADCOMM. (2009). Communications glossary. Management Briefing N0 1. ADCOMM Engineering.

[3] Addler, R. B. (2000). Understanding Human Communication. Harcourt: Harcourt College.

[4] Aguis, M. (2014). "The Medical Consultation and the Human Person" in Psychiatria Danubina. Croatia: Zagreb. Vol. 26, Suppl. 1, pp 15-18.

[5] Bach, K. (2006) Impliciture vs. Expliciture. No place: No Publisher.

[6] Bateman, H. at al. (2005). Dictionary of Medical Terms. Fourth Edition. London: A \& C Black.

[7] Bates, E. (1976). Language and context: The Acquisition of Pragmatics. New York: Academic Press.

[8] Berlo, D. (1960). The Process of Communication: An introduction to Theory and Practice. Hott.

[9] Bolinger, D. (1975). Aspects of language. Harcourt: Harcourt College.

[10] Brown, T. H. (1966. Conversational English. Xeron.

[11] Centre National de la Recherche Scientifique. (2005). Focus the Brain.

[12] Coates, G. T. (2009). Notes on Communication: A few thoughts about the way we interact with the people we meet. Free e-book.

[13] fromwww.wanterfall.com

[14] Cohen, M. (2008). “Kaplan on Demonstratives”. Lecture.

[15] Collin, P. H. (2004). Dictionary of Law. Fourth Edition. London: Bloomsbury.

[16] Cruse, A. (2006). A Glossary of Semantics and Pragmatics. Edinburgh: Edinburgh University Press.

[17] Crystal, D. (2008). A Dictionary of Linguistics and Phonetics: Sixth Edition. USA: Blackwell Publishing.

[18] Dijk, T. V. (1977). Text and Context: explorations in the semantics. London: Longman. 
[19] Dixon, T. And M. O'Hara in www.practicebaselearning.org

[20] Flexner, S. B. And L. C. Hauck. (1987). The Random House Dictionary of the English Language: Second edition. New York: Random House.

[21] Grabski, W. And D. Nowak. (2009). Guide to the Practical Course in Clinical Medicine. Lodz: Medical University of Lodz.

[22] Griffiths, P. (2006). An Introduction to English Semantics and Pragmatics. Edinburgh: Edinburgh University Press.

[23] Ha, J. F. And Longnecker, N. (2010). "Doctor-Patient Communication: A Review" in the Ochsner Journal. Louisiana: Ochsner Journal, vol. 10 spring, pp 38-43.

[24] Ja'far, A. A. (2007). Entailment and Presupposition. Babylon: Babylon University.

[25] Jackendoff, R. (1989). "What is a Concept, that a Person May Grasp?" in Mind \& Language. Vol. 4 Nos. 1 and 2 Spring/Summer 1989. Brasil: Brasil Blackwell.

[26] Kopczynski, A. (1980). Conference interpreting: some linguistics and communicative problems.

[27] Leech, G. (1974). Semantics.

[28] Longman. (1992). Longman Dictionary of English Language and Culture Great Britain: Longman Group UK.

[29] Miller, G. (1973). Communication, Language and meaning: Psychological perceptive.

[30] Potts, C. (2014). Presupposition and Implicature. Stanford: Stanford Linguistics.

[31] Richards and Smith. (1983). Language and Communication. London: Longman.
[32] Richards, J. C. and R. Schmidt (2010) Longman Dictionary of Language Teaching and Applied Linguistics. Fourth Edition. Great Britain: Longman.

[33] Scott, A. F. (1962). Meaning and style. Macmillan.

[34] Searle, J. R. (2006). What is Language: Some Preliminary Remarks. Self, L. S. And C. S. Carlson-Liu. (1988). Oral Communication skill: A Multicultural Approach. USA: Publishing Company.

[35] Shaw, H. (1972) Dictionary of literary terms. New York: Mcgraw-Hill Book Company.

[36] Speaks, J. (2007). "Double-Indexing and the Kaplan semantics". Lecture.

[37] Stanford Encyclopedia of Philosophy. (2014). Theories of Meaning

[38] Stanford Encyclopedia of Philosophy. (2015). Theories of Meaning

[39] Steinberg, D. (1971). Semantics: An interdisciplinary reader in philosophy, linguistics and Psychology. Cambridge: Cambridge University Press.

[40] Velentzas, J. And G. Broni (-----) Communication cycle: Watson, J. and A. Hill. (2012) Dictionary of Media and Communication studies. $8^{\text {th }}$ Edition. New York: Bloomsbury.

[41] Widdowson, H. G. (1960). Teaching Language as Communication. Oxford: Oxford University Press.

[42] www.free-management-ebooks.com

[43] Yang, H. S. (2014). The Use of Questions and the Consequences for face work in Media discourse: An Empirical Analysis of the Jeremy Kyle Show. Brighton: The University of Brighton. 